\title{
Vegetation mapping of moss-dominated areas of northern part of James Ross Island (Antarctica) and a suggestion of protective measures
}

\author{
Miloš Barták ${ }^{1 *}$, Peter Váczi ${ }^{1}$, Zdeněk Stachoň ${ }^{2}$, Svatava Kubešová ${ }^{3,4}$ \\ ${ }^{1}$ Department of Experimental Biology, Laboratory of Photosynthetic Processes, Faculty \\ of Science, Masaryk University, University Campus - Bohunice, Kamenice 5, 62500 \\ Brno, Czech Republic \\ ${ }^{2}$ Department of Geography, Faculty of Science, Masaryk University, Kotlářská 2, 61137 \\ Brno, Czech Republic \\ ${ }^{3}$ Department of Botany and Zoology, Faculty of Science, Masaryk University, University \\ Campus - Bohunice, Kamenice 5, 62500 Brno, Czech Republic \\ ${ }^{4}$ Moravian Museum, Department of Botany, Hviezdoslavova 29a, 62700 Brno, Czech \\ Republic
}

\begin{abstract}
James Ross Island is a large $\left(2500 \mathrm{~km}^{2}\right)$ island situated in the north-western part of the Weddell Sea, close to the northern tip of the Antarctic Peninsula. The island is rich in vegetation oases, i.e. areas covered by autotrophic organisms comprising a great variety of terrestrial algae, cyanobacteria, lichens and mosses. In this study, a GPS method was used to measure moss-dominated vegetation areas located at northern part of James Ross Island. Several small-scale (above $400 \mathrm{~m}^{2}$ ) areas were selected for the measurements of their shape, total area, boarder line, mean slope, and exposition as well as biodiversity of mosses. The areas of interest were located particularly in neighbourhood of the Big and Small Lachman lakes and northern slopes of Berry Hill mesa. Typically, the mossdominated areas were supplied with melt water from neighbouring snow fields formed in previous austral winter season. Specimens of mosses were collected from each site so that dominating species forming community structure could be evaluated. Individual areas differed in species richness, however, Bryum pseudotriquetrum and Hypnum revolutum dominated most of them. Sanionia uncinata was found at the only one of the investigated areas and might be considered as rare species for James Ross Island. In the paper, shape location and area of moss-dominated spots at James Ross Island is reported and discussed in relation to morphological characteristics of particular sites as well as water availability during austral summer season. Potential of the data for geographical information systems (GIS), further application of unmanned aerial vehicle (UAV) in vegetation mapping, and spectral reflectance parameters measurements of Antarctic moss-dominated areas are discussed. For particular areas, protective measures are suggested to minimize human disturbance of the sites and provide a platform for a longterm study of biodiversity.
\end{abstract}

Received June 1, 2015, accepted August 25, 2015.

*Corresponding author: Miloš Barták <mbartak@sci.muni.cz>

Acknowledgements: The authors thank the CzechPolar infrastructure, J.G.Mendel station at James

Ross Island in particular, for help and support. 
M. BARTÁK et al.

Key words: Antarctics, mosses, seepages, biodiversity, Bryum pseudotriquetrum, Hypnum revolutum, Sanionia uncinata

DOI: $10.5817 / C P R 2015-1-8$

\section{Introduction}

James Ross Island $\left(2500 \mathrm{~km}^{2}\right)$ is located near the east coast of Antarctic Peninsula at the geographical coordinates $63^{\circ} 47^{\prime} \mathrm{S}-64^{\circ} 27^{\prime} \mathrm{S}$ and $57^{\circ} 05^{\prime} \mathrm{W}-58^{\circ} 24^{\prime} \mathrm{W}$. The island is made of Cretaceous marine sediments cropping mostly out at the lower altitudes covered by Neogene and Quaternary volcanic sequences intercalated with glacigennic and glaciomarine sediments (Francis et al. 2006). Recently, majority of James Ross Island surface is covered with glaciers. The northernmost part of the island that forms, however, represents one of the largest ice-free areas along the northern part of the Antarctic Peninsula (about $20 \%$ of total area). The area is available for colonization by autotrophic organisms, mosses and lichens in particular. Due to geomorphology and limited water availability, however, vegetation cover is rather patchy and forming small-area green spots.

Since 2007, after the start-up of Czech scientific station J.G. Mendel (Prošek et al. 2012), long-term research of structure and function of deglaciated ecosystems and their components has been performed. Recent research direction carried out by Czech scientist at James Ross Island cover a wide array of disciplines of terrestrial ecology. Among those studying biological elements of Antarctic ecosystems, main emphasis is given the environmental changes effects on biodiversity and ecophysiological characteristics of autotrophs. The impacts of natural climate variation and ongoing change on glaciers, permafrost, lakes, streams, seepages and other geosphere elements available for vegeta- tion growth and development are studied. Moreover, global warming effects on vegetation characteristics are studied using an open top chamber approach (OTC- Barták et Váczi 2014).

The polar flora coastal regions is composed mainly of bryophytes and lichens (Longton 1982). In Antarctica, these autotrophic organisms are well adapted to short summers and low temperatures (Putzke et Pereira 2001). Such climatic conditions inhibit the reproductive cycle, limiting the diversity and the gene pool, especially for flowering plants (Pereira et Putzke 1994, Vincent 2000). The Antarctic hair grass (Deschampsia antarctica) and the Antarctic pearlwort (Colobanthus quitensis) are the only native angiosperms growing in Antarctica, but are restricted to the maritime Antarctica, and thus not present at James Ross Island which is recently considered as a dominant island of a rather small North-east Antarctic Peninsula biogeographic region delimited by Terauds et al. (2012). Since it represents a transition region between maritime and continental Antarctica, biodiversity of moss and lichen flora is limited by climatic factors (Láska et al. 2011). Generally, flora of James Ross Island is composed of mosses, lichens and microautotrophs such as terrestrial algae and cyanobacteria. For James Ross Island, much less moss species is reported than for a great number of localities in the Southern Shetlands archipelago, King George Island in particular. The Southern Shetlands has been investigated repeatedly by bryologists since the 70 -ies, and thus a comprehensive list of moss species is avail- 
able in literature for particular islands: Elephant Island (Allison et Smith 1973), King George Island (see e.g. Furmanczyk et Ochyra 1982, Ochyra et al. 2008, Casanovas et al. 2013).

Altogether 49 moss and 144 species that are reported for James Ross Island in the British Antarctic Survey database (BAS see Other sources for web page) and summarized by Barták (2014). Within last few decades, several studied addressed to particular aspects of presence, taxonomic and ecological characteristics of several moss species at James Ross Island were done. They report several species, such as e.g. Ceratodon purpureus (Clarke 2008), Platydictia jungermannoides, Didymodon brachyphyllus / Bryoerythrophyllum antarcticum.

Majority of moss species that have been determined and reported for James Ross Island, however, come from specimen collected from sites south of $63^{\circ} 50^{\prime}$, Brandy Bay area in particular. Therefore, biodiversity of mosses and distribution of moss-dominated areas at Northern part of James Ross Island is much less know then e.g. in Santa Martha Cove and other places sampled by R.I. Smith in 1989.

Vegetation mapping in Antarctica represent an important tool to learn more about recent patterns of vegetation cover, their components in particular, and dynamics of ongoing changes in vegetation cover. If field survey is supplemented with remote sensing approach, spectral reflectance indices, such as e.g. NDVI and PRI may serve for functional analysis of the species forming the vegetation cover and their responses to a variety of environmental factors. In Antarctica, such ap- proach was applied first by Fretwell et al. (2011). Since that time, remote sensing has been used for vegetation mapping purposes in several locations in Antarctica e.g. Barton Peninsula (King George Island - Shin et al. 2014), Hennequin Point (King George Island - Victoria et al. 2013).

The aim of this paper is to describe moss-dominated areas of the northern coast of James Ross Island using a finescale mapping approach in order to provide a cartographic base for future monitoring studies. We expect, similarly to the findings of Victoria et al. (2009), differences in shape of such small mossdominated areas as well as their species composition can be found within a course of time due the heterogeneity in terrain, microtopography, substrate type and chemistry. Another aim of this paper is to provide a platform for protection of the components of vegetated terrestrial ecosystems of James Ross Island. In future, we consider to bring some more detailed information on community structure and suggestions for measures to manage and coordinate human activities in the area in such a way as to provide long-term protection to the values of moss-dominated vegetation spots on the northern part of James Ross Island. In this paper, we consider to follow several protective measures for 6 small-area vegetation spots. The measures would be similar to those applied within the system of Antarctic Specially Protected Areas (ASPAs) or Antarctic Specially Managed Area (ASMAs). Such future development would provide the area-based tools relevant to research field activities, rules, tourism regulation and management, complemented by zoning and site guidelines. 


\section{Material and Methods}

In austral summer 2015 (Jan.-Feb.), a detailed mapping of moss-dominated vegetation oases larger than $400 \mathrm{~m}^{2}$ and characterization of their plant communities was carried out on northern part of James Ross Island along the coastal line from Bibby Point to Bengtson Cliffs (see Table 1). The first field survey of ice-free terrain resulted

\section{Location of moss-dominated areas}

Area, border line and vegetation cover were evaluated on 6 particular areas. The first one is a long-term research plot (Area No. 1 in Fig. 1, LTRP) located close to a coastal line in between the confluxes of the Bohemian and Algal streams. The area is dominated by Bryum pseudotriquetrum that forms carpets, a longitudinal axis of which follows the line of thawing water pathway from a temporary snowfield located hillside $50 \mathrm{~m}$ away from the area. The area is composed of two subareas and rich in microbial mats formed by Nostoc sp. colonies (Trnková, in prep.), algal (e.g. Zygnema sp.) and cyanobacterial species at in a count and list of small-area spots that were dominated by mosses. Among these spots, 6 were selected for further mapping - see details in Fig. 1 - since, thanks to different geomorphology, snow accumulation formation, and water availability, they represented typical but different wet environments.

the bottom of shallow streams vegetatively active for a short term period during austral summer (Komárek 2013, 2014). Out of moss carpet area, a stony surface is covered patchilly by lichens, such as e.g. Rhizoplaca melanopthalma, Xanthoria elegans (M. Barták - unpublished data). Multidisciplinary research of LTRP is carried out by the investigations of mineral elements availability (Zvěrina et al. 2012), microclimatological parameters and vegetation responses to manipulated warming of atmosphere (Barták et Váczi 2014) and soil microbiology (unpublished data).

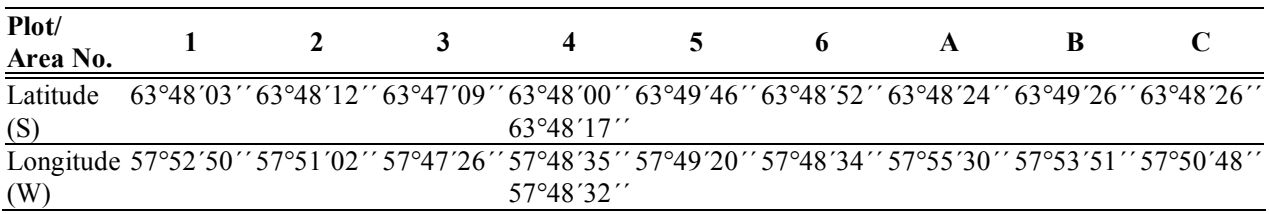

Table. 1. Geographic co-ordinates of moss-dominated areas located at northern part of James Ross Island reported in this study.

The Area No. 2 (see Fig.1) comprises four distinct subareas. Each subarea represents a moss carpet of irregular shape related to individual water stream. The area is located on a $\mathrm{N}$-facing slope and fed by several snowfields located on northern foothill of the Berry Hill mesa. Thus, the longitudinal axes of the subareas reflect fall lines and the subareas extending with their terminal part close to a sea shore, where cliffs inclination and mechanical disturbance caused by raw mineral material transport do not allow permanent establishment of vegetation cover. The area is named Komárek's slopes. Bottoms of streams are rich in cyanobacterial and algal species (see e.g. Skácelová et al. 2015). Several moss species form individual moss carpets, however Bryum pseudotriquetrum and Hypnum revolutum dominate the com- 
munity (see Fig. 4D). The Area No. 3 is located close to a sea shore and represents a small moss-dominated area sheltered from a northern side by a rock $(116 \mathrm{~m}$ a.s.l., Cape Lachman). The side is slightly inclined to SE. It is dominated by Hypnum revolutum. In the area, a microclimate automatic station has been established in order to evaluate microclimate effects on permafrost (unpublished). The Point 4 area is a relatively large area composed of several subareas fed by a large snow field adjacent to Small Lachman Lake from W side. The persistence of a snow field for almost whole austral summer season enables vegetation cover to grow and develop because water is available throughout whole growing season. The moss carpets at the place had $\mathrm{E}$ to $\mathrm{W}$ longitudinal axes and end in a very neighbourhood of the lake. Generally, a W neighbourhood of Big Lachman Lake, Interlagos, and Small Lach- man Lake is very rich in green spots formed by dominating mosses and algal/ cyanobacterial mats. The mats are rich in a great variety of algae and cyanobacteria here covering bottom of small streams and smallarea ponds (Váczi et Barták 2011). Some of green spots, however do not reach an area of $400 \mathrm{~m}^{2}$ and thus were not included into this study. The Area No. 5 is located in a shallow valley that is fed by a stream originating in a snowfiled formed on SEfacing slopes (see Fig.1). The area is formed in a relatively flat landscape in between and close to a number of individual boulders of irregular shapes and dimensions (height ranging from 0.5 to $2.5 \mathrm{~m}$ ). Among the moss species present at the site, a dominant Hypnum revolutum could be mentioned as well as Sanionia uncinata which is quite rare at the site and James Ross Island compared to South Shetlands.

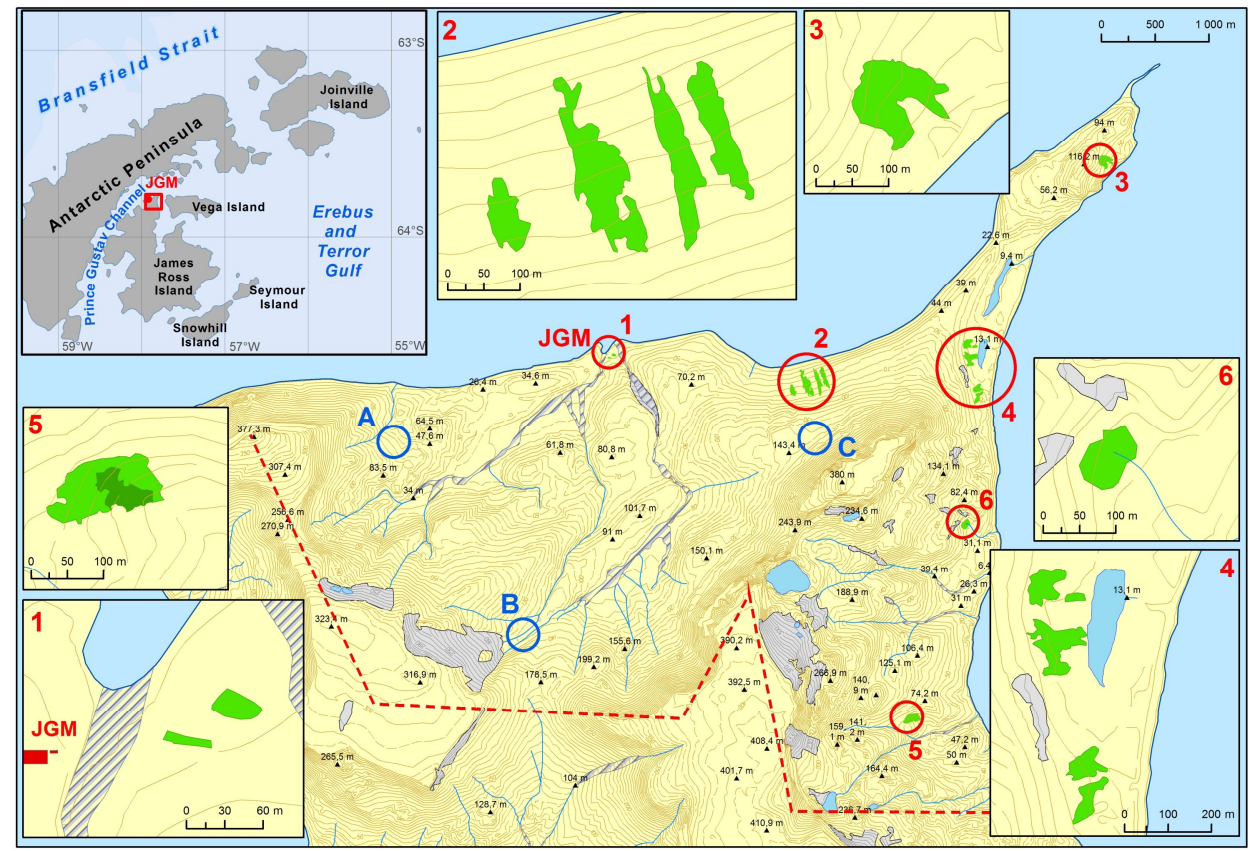

Fig. 1. Northern part of James Ross Island. Area of interest is delimited by a red line and a coastal line. Locations of small-area lichen dominated spots are indicated by circles. Blue symbols and characters indicate those areas surveyed during field works but not included into this study. Red symbols and numbers indicate those that were mapped during 2015 austral summer season. 


\section{Mapping procedure}

The five areas were mapped using a walk along the outer margins of green spots that were formed by moss carpet. GPS data were recorded using a GPS computer (Garmin Edge 705, Garmin, Taiwan). The margins of uninterrupted moss carpet were defined as those at which a single square meter area was covered by $50 \%$ by mosses. Wherever the relative moss cover decreased below $50 \%$ of a single square meter, the area was considered

\section{Long-term data measurements}

Several scientific zones and particular sites of long-term measurements are established within the areas (Areas 1-6) to collect long-term climatic data. They comprise mainly permanent authomatic weather stations and points at which seasonal measurement are performed. They comprise 1) Long-term research plot (Area No. 1) located close to J. G. Mendel station at which a research of the effects of manipulated warming on vegetation has been conducted since 2007 using an open top chamber approach (Barták et Váczi 2014), 2) microclimatic stations characterizing local climate of Komarek's slopes

\section{Results and Discussion}

\section{Community-forming moss species}

Moss carpets, their species composition, respectively are formed by several moss species. Dominant species are shown for particular area in Figs. 2-7. In LTRP (Area No. 1), Bryum pseudotriquetrum dominates. The other areas (Areas 2-4) are typical by Hypnum revolutum, Bryum argenteum, and Schistidium halinae. Relative share of the species is, however, sitespecific. The above-specified species are reported for the northern part of James Ross Island by the BAS database and as outside the moss-dominated area. An ESRI GIS software (ArcGIS 10.2) was used, yielding GPS collected data after post-processing with software using a topographic map of James Ross Island - northern part ( $1: 25000$, see Other sources). Whenever nestled into the map, individual areas were visualized and their area, mean slope, exposition calculated using the above-specified software.

area $\left(63^{\circ} 48^{\prime} 18^{\prime \prime} \mathrm{S}, 57^{\circ} 50^{\prime} 22^{\prime \prime} \mathrm{W}-\right.$ pedological/solifluction reserch plot) and Cape Lachman area (63 $47^{\circ}$ '09', S, $57^{\circ} 47^{\prime} 19^{\prime}$ ' W - permafrost research plot), and 3) small-area freshwater ponds located in between Big and Small Lachman Lake (called Interlagos, Váczi et Barták 2011), where seasonal measurements of dissolved oxygen lasting typically for 4-5 week take place. Research activities in all these zones are carried out with particular care to avoid or minimize disturbance of wildlife, trampling of vegetation and interference with on-going research.

based on the collections made by R. I. Smith and R. G. Booth in the 80-ies of the last century. Those species were determined later by R. Ochyra. The list of species is, however, incomplete because of the fact that many moss-dominated areas in northern part of James Ross Island have not yet been sampled. Recently, a group of Czech experts is going to update the list after determination of specimens collected within the period of 2010-2015. 

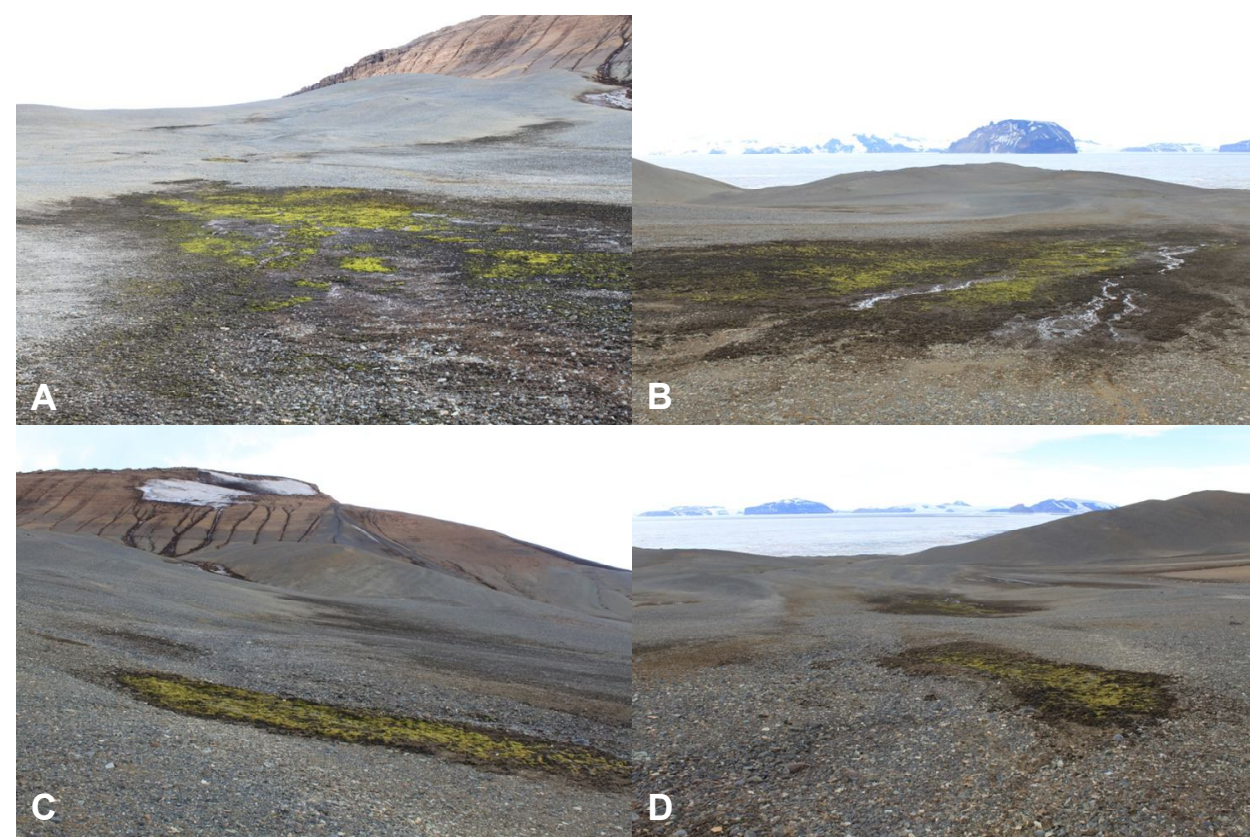

Fig. 2. Small areas located on NW slopes of the Johnson mesa denoted as $A$ in this study ( $c f$. also Fig. 1). A - general view, B, C, D - individual areas.

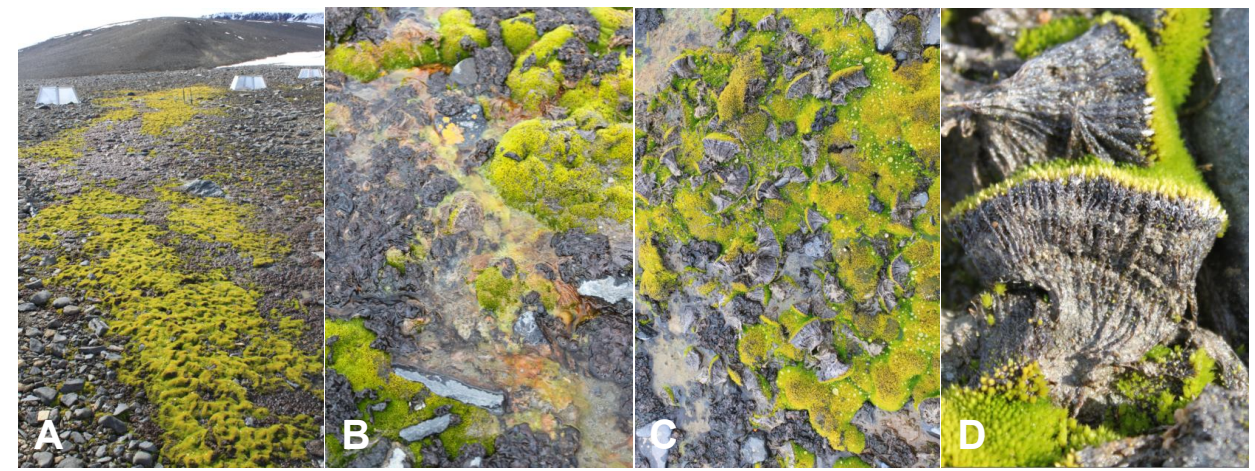

Fig. 3. Moss carpets dominated by Bryum pseudotriquetrum at Area No. 1 located at the long-term research plot close to J.G.Mendel station. A - general view with open top chambers, B, C - patchy moss cover with Nostoc sp. colonies in between, D - side view on a moss.

Areas, and their border lines

Area No. 1 consisted of two distinguished subareas (see Fig. 1). Both subplots benefitted from melt water available from a neighbouring snow field. Effect of melt water was even more apparent in case of Area 2, which consisted from 4 separate 
subareas borders and main longitudinal axes were affected by melt water streams and adjacent seepages (see Fig. 4). The subareas were inclined $10^{\circ}$ and facing north reflecting local geomorphology. Areas No. 3 and 4 were oriented SE and E, respectively, and fed by a melt water from snow accumulations created by $\mathrm{W}$ or SW winds during winter time. Area 4 consisted of several subareas according to microrelief and prevailing direction of water streams to Small Lachman Lake or coastal line. Area No. 5 represented one of the most developed moss-dominated spot. Therefore, the outer boarder line was determined according to the procedure specified in Materials and Methods, while the inner line and the area indicated in deep green represented the places fully coved by a moss carpet. Size, location and shape of the Area 5 suggested that the vegetation is supplied by water available from snow deposition (not seen at the time of observation, i.e. February 2015) formed in an amphitheatre-like depression and in between large boulders (see Fig. 7) located at the site. We speculate, that thank to the presence of the boulders, thickness of snow layer might be higher then in the surroundings since they represent and aerodynamic obstacle promoting snow deposition on a leeward side. Similarly, Area
No. 6 benefitted from a SE-facing depression that helped to accumulate a snowpack. Melt water enabled the moss-dominated area to be formed and survive at the place.

In future, a more detailed mapping of small-area moss-dominated vegetation oases is planned covering southern parts of ice-free area of James Ross Island. Database of moss-dominated vegetation cover will be enlarged especially by the localities in Solorina valley, Santa Martha Cove and numerous green spots in Abernathy flats and areas adjacent to Monolith Lake and Phormidium Lake. Additionally, some locations at James Ross Island that have been included into a long-term research of Antarctic terrestrial ecosystems resilience within the RACER framework (anonymous team members 2015) will be studied, biodiversity of mosses and lichens in particular. Thanks to the promising results of other teams working in vegetation mapping in Antarctica (Jawak et Luis 2015, Lucieer et al. 2010, Turner et al. 2014,), next Czech expeditions to James Ross Island will apply an unmanned aerial vehicle (UAV) approach to study vegetation components of Antarctic oases with a special attention to spectral reflectance of mosses and lichens in dependence on species, age and hydration status.

\begin{tabular}{|c|c|c|c|c|}
\hline Area Plot No. & Area $\left(\mathrm{m}^{2}\right)$ & Elevation $(\mathrm{m})$ & Slope (degree) & Aspect \\
\hline 1 & 837.9 & 3.4 & 4.3 & NW \\
\hline 2 & 27443.9 & 52.7 & 10.0 & N,NW \\
\hline 3 & 8968.7 & 57.4 & 13.6 & E,SE \\
\hline 4 & 20758.7 & 17.7 & 17.7 & NE,E,SE \\
\hline 5 & 9435.2 & 46.2 & 10.2 & SE \\
\hline 6 & 4410.2 & 39.1 & 4.5 & E \\
\hline
\end{tabular}

Table. 2. Geoinformatic parameters of the vegetated, moss-dominated areas involved into the vegetation mapping reported in this study. 
MOSSES OF JAMES ROSS ISLAND

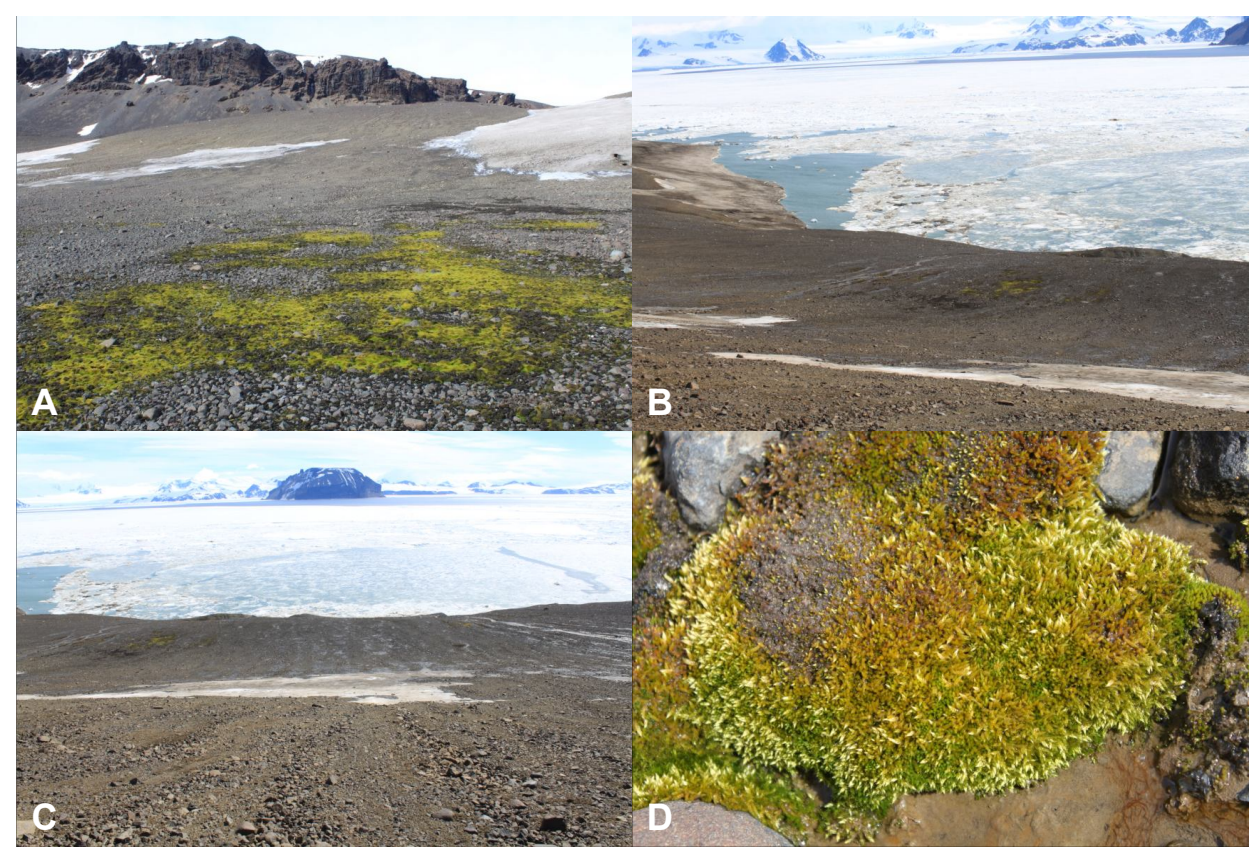

Fig. 4. Area No. 2 located at Komarek's slopes. A - general view from northern side, B, C general view from souther side, $\mathrm{D}$ - Hypnum revolutum.

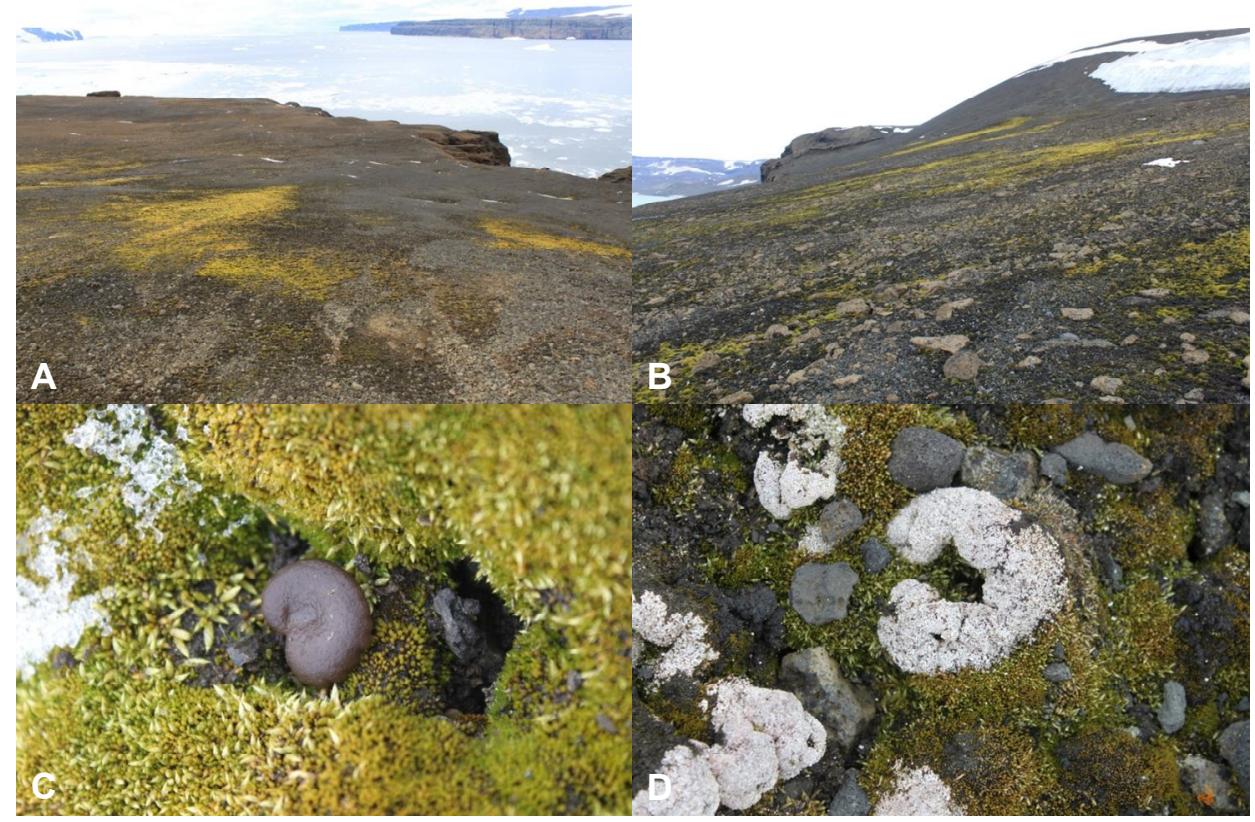

Fig. 5. Area No. 3 located at the Cape Lachman. A - general view from northern side, B - general view from eastern side, $\mathrm{C}-$ Arrhenia $\mathrm{sp}$. is found at the plot, $\mathrm{D}$ - moss and lichen cover. 


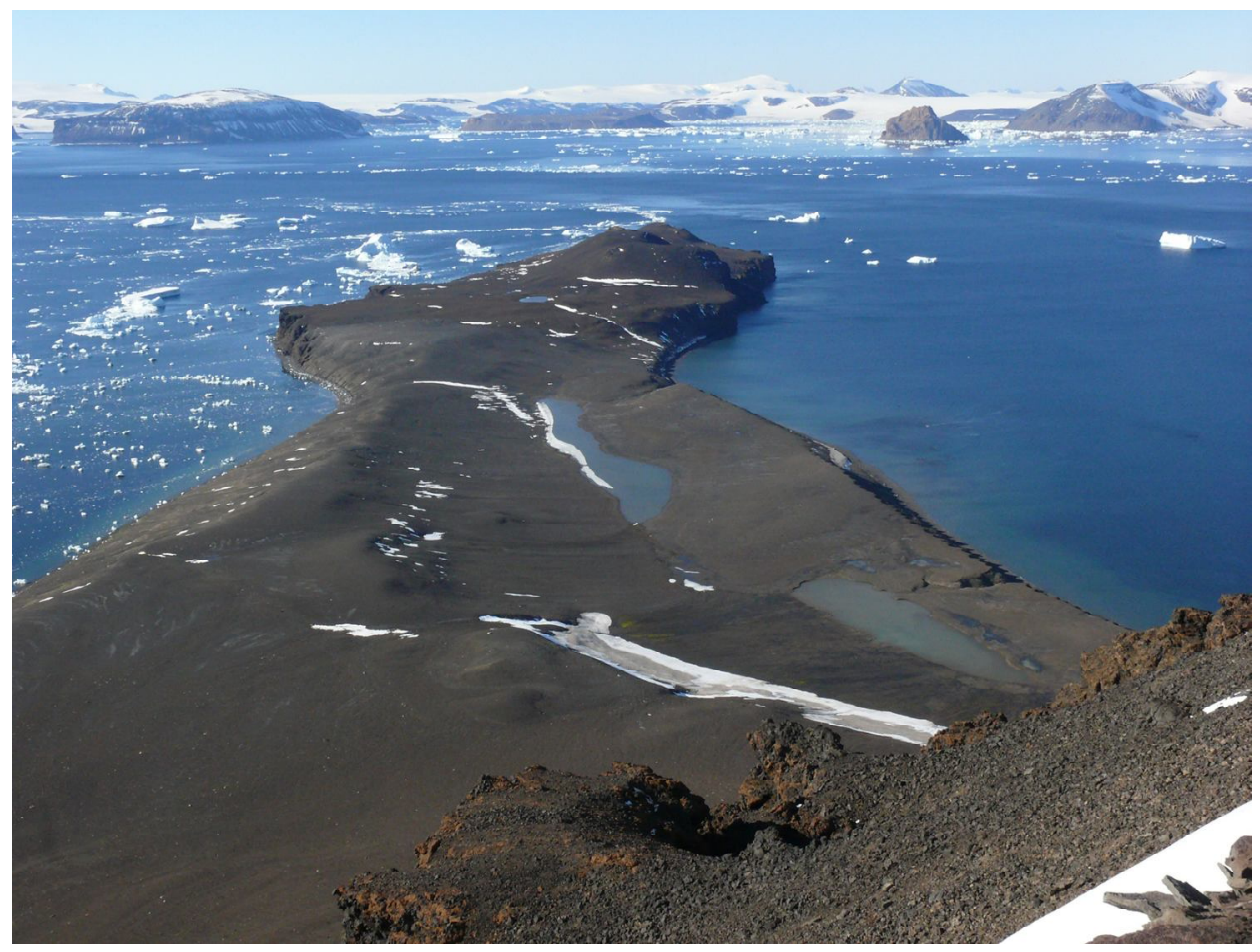

Fig. 6. Big and Small Lachman Lake with seepages denoted as Area No. 4 in this study. The moss dominated seepage is located between a snow field and a lake.

\begin{tabular}{|c|l|}
\hline Measure No. & Measure description \\
\hline 1 & $\begin{array}{l}\text { Creation and regular update of GPS co-ordinates database of sampling } \\
\text { points in the area(s) No. 1-6., and A-D. }\end{array}$ \\
\hline 2 & $\begin{array}{l}\text { Any installation of a new weather stations, data loggers, field technical } \\
\text { installations, their modifications, or removal should be consulted with } \\
\text { appropriate Czech expedition members staying at Mendel station first. }\end{array}$ \\
\hline 3 & $\begin{array}{l}\text { Scientists staying at James Ross Island during austral summer season should } \\
\text { avoid walking in the areas 1-5 when moist and thus susceptible to } \\
\text { disturbance of natural arrangement of the upper soil layer }\end{array}$ \\
\hline 4 & $\begin{array}{l}\text { Scientist and tourists should follow the rules of general protection of the } \\
\text { areas because of important scientific and ecological values (no crossing the } \\
\text { areas, no collection of vegetation except of scientific purposes) }\end{array}$ \\
\hline 5 & $\begin{array}{l}\text { No tourists walks allowed through the areas 1-5 after their landing at JRI, } \\
\text { especially in the Area No.1 (a special corridor is suggested for tourist walk } \\
\text { along the LTRP No. 1) }\end{array}$ \\
\hline
\end{tabular}

Table. 3. A list of measures proposed for the small-area moss-dominated areas of the northern part of James Ross Island. 


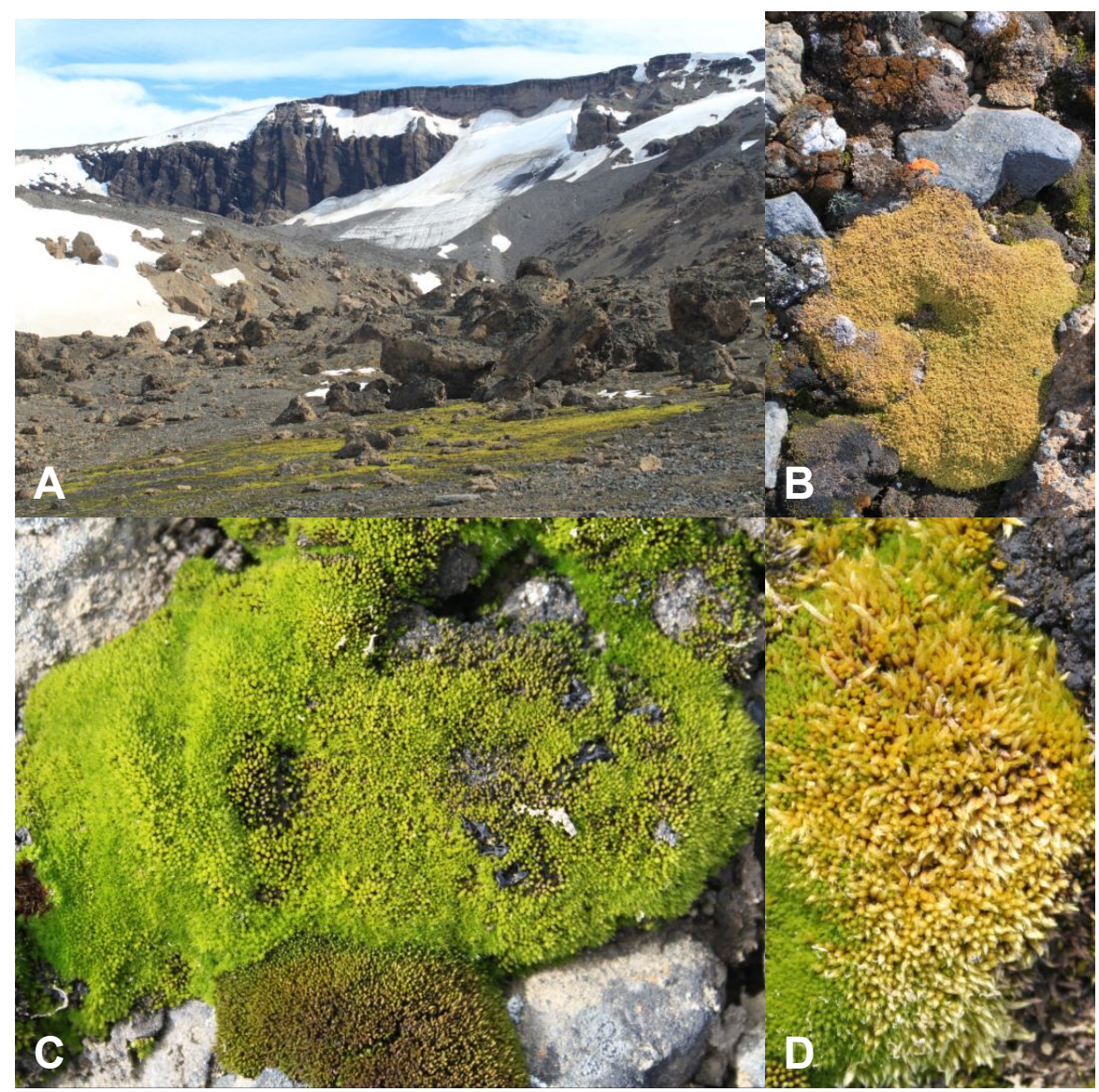

Fig. 7. Area No. 5 located close to Lachman Crags mesa. A - general view, B - Sanionia uncinata, $\mathrm{C}$ - Bryum pseudotriquetrum, D - Hypnum revolutum.

\section{Conclusions}

In this paper, preliminary results of mapping of moss-dominated vegetation oases at northern part of James Ross Island are presented. Among numerous small-scale moss-dominated areas, five were chosen for fine-scale mapping with a special emphasis to evaluate irregular borders of the areas and dominant moss species. Since moss and lichen species are known to be incompletely surveyed at James Ross Island, further field work will be focused on more detailed analysis of community structure, use of UAVs with spectral reflectance camera, so that species-specific patchi- ness could be evaluated. In future, we consider to evaluate vegetation indices for the moss-dominated areas and, similarly to Bricher et al. (2013) implement them to digital elevation model (DEM) of James Ross Island. This approach is considered to be money saving strategy with a great potential for vegetation mapping (see e.g. Salami et al. 2014, Turner et al. 2012, 2014). For future, the following measures are suggested in order to optimize field research activities and provide the areas a reasonable protection. 


\section{References}

Allison, J.S., Smith, R.I.L. (1973): The vegetation of Elephant Island, South Shetland Island. British Antarctic Survey Bulletin, 33-34: 185-212.

BARTÁK, M. (2014): Biodiversity of microorganisms, lichen and moss flora (in Czech). In: P. Prošek (ed.): Antarktida. Prague, Academia, The Publishing House of the Academy of Sciences of the Czech Republic, pp. 311-317.

BARTÁK, M., VÁCZI, P. (2014): Long-term fluorometric measurements of photosynthetic processes in Antarctic moss Bryum sp. during austral summer season. Czech Polar Reports, 4: 63-72.

Bricher, P. K., Lucieer, A., Shaw, J., Terauds, A. and Bergstrom, D. A. (2013): Mapping SubAntarctic Cushion Plants Using Random Forests to Combine Very High Resolution Satellite Imagery and Terrain Modelling. PLoS ONE, 8(8): e 72093. doi:10.1371/journal.pone.0072093.

Casanovas, P., Lynch, H. J. and Fagan, W. F. (2013): Multi-scale patterns of moss and lichen richness on the Antarctic Peninsula. Ecography, 36: 209-219.

Clarke, L.J. (2008): Resilience of the Antarctic moss Ceratodon purpureus to the effects of elevated UV-B radiation and climate change. Ph.D. thesis, University of Wollongong. $191 \mathrm{p}$.

Francis, J. E., Pirrie, D. and Crame, J. A. (2006): Cretaceous-Tertiary High-Latitude Palaeoenvironments, James Ross Basin, Antarctica. Geological Society, London, Special Publications, 258, London, pp. 1-5.

Fretwell, P.T., Convey, P., Fleming, A.H., Peat, H.J. and Hughes, K.A.(2011): Detecting and mapping vegetation distribution on the Antarctic Peninsula from remote sensing data. Polar Biology, 34: 273-281.

FuRMANCZYK, K., OchYRA, R. (1982): Plant communities of the Admiralty Bay (King George Island, South Shetland Islands, Antarctic). I. Jasnorszewski Gardens. Polish Polar Research, 3 : 25-39.

JAWAK, S. D., Luis, A. J. (2015): A Rapid Extraction of Water Body Features From Antarctic Coastal Oasis Using Very High-Resolution Satellite Remote Sensing Data. Aquatic Procedia, 4: $125-132$.

KomÁReK, J. (2013): Phenotypic and ecological diversity of freshwater coccoid cyanobacteria from maritime Antarctica and islands of NW Weddell Sea. I. Synechococcales. Czech Polar Reports, 3: 130-143.

KomÁreK, J. (2014): Phenotypic and ecological diversity of freshwater coccoid cyanobacteria from maritime Antarctica and islands of NW Weddell Sea. II. Synechococcales. Czech Polar Reports, 4: 17-39.

Láska, K., Barták, M., Hájek, J., Prošek P. and Bohuslavová, O. (2011): Climatic and ecological characteristics of deglaciated area of James Ross Island, Antarctica, with a special respect to vegetation cover. Czech Polar Reports, 1: 49-62.

LONGTON, R.E. (1982): Bryophyte vegetation in polar regions. In: A.J.E. Smith (ed.): Bryophyte ecology. London: Chapman and Hall, 123-165 pp.

LuCIEER, A., RoBinson, S. A. and TuRner, D. (2010): Using an unmanned aerial vehicle (UAV) for ultra-high resolution mapping of Antarctic moss beds. In: Proceedings of 2010 Australasian Remote Sensing \& Photogrammetry Conference, Alice Springs, NT, Australia, 14-16 September 2010; pp. 1-12.

Ochyra, R., Lewis Smith, R.I. and Bednarek-Ochyra, H. (2008): The illustrated moss flora of Antarctica. Cambridge: Cambridge University Press, $685 \mathrm{p}$.

Pereira, A.B., Putzke, J. (1994): Floristic composition of Stinker Point, Elephant Island, Antarctica. Korean Journal of Polar Research, 5:37-47.

ProšeK, P., BARTÁK, M., LÁSKA, K., SUCHÁNeK, A., HÁJEK, J. and KAPLER, P. (2012): Facilities of J. G. Mendel Antarctic station: Technical and technological solutions with a special respect to energy sources. Czech Polar Reports, 3: 38-57.

Putzke, J., Pereira, A. B. (2001): The Antarctic mosses with special reference to the Shetland Island. Canoas, Lutheran University of Brazil, Editora da Ulbra, 196 p.

Salamí, E., BARRAdO, C. and PAStor, E. (2014): UAV Flight Experiments Applied to the Remote Sensing of Vegetated Areas. Remote Sensing, 6: 11051-11081. 
ShIN, J., KIM, H.-CH., KIM, S. and Hong, S. G. (2014): Vegetation abundance on the Barton Peninsula, Antarctica: estimation from high-resolution satellite images. Polar Biology, 37: 1579-1588.

SkÁcElovÁ, K., HrbÁČEK, F., ChATtovÁ, B., LÁSKA, K. and BARTÁK, M. (2015): Biodiversity of freshwater autotrophs in selected wet places in northern coastal ecosystems of James Ross Island. Czech Polar Reports, 5: 12-26.

Terauds, A., Chown, S. L., Morgan, F., Peat, H. J., Watts, D. J., Keys, H., Convey, P. and Bergstrom, D. M. (2012): Conservation biogeography of the Antarctic. Diversity and Distributions, 18: 726-741.

Turner, D., Lucieer, A. and Watson, Ch. (2012): An Automated Technique for Generating Georectified Mosaics from Ultra-High Resolution Unmanned Aerial Vehicle (UAV) Imagery, Based on Structure from Motion (SfM) Point Clouds. Remote Sensing, 4: 1392-1410.

Turner, D., Lucieer, A., MalenovskÝ, Z., King, D. H. and Robinson, S.A. (2014): Spatial CoRegistration of Ultra-High Resolution Visible, Multispectral and Thermal Images Acquired with a Micro-UAV over Antarctic Moss Beds. Remote Sensing, 6: 4003-4024.

VÁCZI, P., BARTÁK, M. (2011): Summer season variability of dissolved oxygen concentration in Antarctic lakes rich in cyanobaterial mats. Czech Polar Reports, 1: 42-48.

Victoria, F. C., Albuquerque, M. P., Pereira, A. B., Simas, F. N. B., Spielmann, A. A. and SCHAEFER, C.E.G.R. (2013): Characterization and mapping of plant communities at Hennequin Point, King George Island, Antarctica. Polar Research, 32, 19261, http://dx.doi.org/10.3402/ polar.v32i0.19261.

Victoria, F. C., Pereira, A. B. and Costa, D. P. (2009): Composition and distribution of moss formations in the ice-free areas adjoining the Arctowski region, Admiralty Bay, King George Island, Antarctica. Iheringia Série Botânica, 64: 81-91.

VINCENT, W.F. (2000): Evolutionary origins of Antarctic microbiota: invasion selection and endemism. Antarctic Science, 12: 374-385.

ZvĚŘina, O., Coufalík, P., Vaculovič, T., Kuta, J., Zeman, J. and KomÁReK, J. (2012): Macroand microelements in soil profile of the moss-covered area in James Ross Island, Antarctica. Czech Polar Reports, 2: 1-7.

\section{Other sources}

Anonymous (2015): Antarctic trial of WWF's Rapid Assessment of Circum-Arctic Ecosystem Resilience (RACER) Conservation Planning Tool: Results of RACER workshop focused on James Ross Island. Information paper by Great Britain and Czech Republic, $38^{\text {th }}$ Antarctic Treaty Consultative Meeting, Sofia, Bulgaria 2015, 33 p.

Anonymous team members (2015): IP 034 Sofia Antarctic trial of WWF's Rapid Assessment of Circum-Arctic Ecosystem Resilience (RACER) Conservation Planning Tool: Results of RACER workshop focused on James Ross Island. Sofia 2015 (ATCM web page).

British Antarctic Survey database (https://www.bas.ac.uk/)

Czech Geological Survey. 2009. James Ross Island - northern part. Topographic map $1: 25000$. First edition. Praha, Czech Geological Survey. ISBN 978-80-7075-734-5. 